\title{
PIK3R1 underexpression is an independent prognostic marker in breast cancer
}

\author{
Magdalena Cizkova ${ }^{1,2,3}$, Sophie Vacher ${ }^{1}$, Didier Meseure ${ }^{4}$, Martine Trassard ${ }^{4}$, Aurélie Susini ${ }^{1}$, Dana Mlcuchova ${ }^{3}$, \\ Celine Callens ${ }^{1}$, Etienne Rouleau ${ }^{1}$, Frederique Spyratos ${ }^{1}$, Rosette Lidereau ${ }^{1}$ and Ivan Bièche ${ }^{1,5,6^{*}}$
}

\begin{abstract}
Background: The present study focused on the prognostic roles of PIK3CA and PIK3R1 genes and additional PI3K pathway-associated genes in breast cancer.

Methods: The mutational and mRNA expression status of PIK3CA, PIK3R1 and AKT1, and expression status of other genes involved in the PI3K pathway (EGFR, PDK1, PTEN, AKT2, AKT3, GOLPH3, WEE1, P7OS6K) were assessed in a series of 458 breast cancer samples.

Results: PIK3CA mutations were identified in 151 samples (33.0\%) in exons 1, 2, 9 and 20. PIK3R1 mutations were found in 10 samples (2.2\%) and underexpression in 283 samples (61.8\%). AKT1 mutations were found in 15 samples (3.3\%) and overexpression in 116 samples (25.3\%). PIK3R1 underexpression tended to mutual exclusivity with PIK3CA mutations ( $p=0.00097)$. PIK3CA mutations were associated with better metastasis-free survival and PIK3R1 underexpression was associated with poorer metastasis-free survival ( $p=0.014$ and $p=0.00028$, respectively). By combining PIK3CA mutation and PIK3R1 expression status, four prognostic groups were identified with significantly different metastasis-free survival $(p=0.00046)$. On Cox multivariate regression analysis, the prognostic significance of PIK3R1 underexpression was confirmed in the total population $(p=0.0013)$ and in breast cancer subgroups.
\end{abstract}

Conclusions: PIK3CA mutations and PIK3R1 underexpression show opposite effects on patient outcome and could become useful prognostic and predictive factors in breast cancer.

Keywords: PIK3R1, PIK3CA, Breast cancer, Breast cancer subtypes, Signaling pathways, Prognostic value

\section{Background}

The phosphatidylinositol 3-kinase (PI3K) pathway has been identified as an important player in cancer development and progression. Following receptor tyrosine kinase activation, PI3K kinase phosphorylates inositol lipids to phosphatidylinositol-3,4,5-trisphosphate. The level of phosphatidylinositol-3,4,5-trisphosphate is regulated by phosphatase activity of PTEN. Signal transmission subsequently leads to PDK1 followed by activation of AKT. AKT then regulates activation of the pathway downstream effectors, including mTOR and subsequently P70S6K as well as other targets such as GSK3, WEE1 or BAD. mTOR has been found to be positively

\footnotetext{
* Correspondence: ivan.bieche@curie.net

'Oncogenetic Laboratory, Institut Curie, Hospital René Huguenin, Saint-Cloud, France

${ }^{5}$ UMR745 INSERM, Université Paris Descartes, Sorbonne Paris Cité, Faculté des Sciences Pharmaceutiques et Biologiques, Paris, France

Full list of author information is available at the end of the article
}

regulated by GOLPH3. The PI3K pathway controls important cellular processes such as protein synthesis, cell growth and proliferation, angiogenesis, cell cycle and survival [1-3].

PI3K pathway deregulation is frequent in tumor cells and can be caused by multiple changes affecting different levels of the signaling cascade. These changes include gene amplifications, mutations and expression alterations. However, various patterns of PI3K pathway changes have been identified in different cancer types. In breast cancer, such events commonly affect receptor tyrosine kinases, PTEN, PIK3CA and, to a lesser degree, $A K T 1$. PIK3CA as well as $A K T 1$ mutations have been described as early events in the breast cancer development process [3-6].

PI3K is a heterodimer and consists of a p110 $\alpha$ catalytic subunit encoded by the PIK3CA gene and a p85 regulatory subunit alpha encoded by the PIK3R1 gene [7-11]. 
The PIK3CA oncogene is a well known site of activating hot spot mutations located in exons 9 and 20, corresponding to the helical (E542K and E545K) and kinase (H1047R) domains, respectively. PIK3CA mutations are among the most common mutations, as they are observed in 10 to $40 \%$ of breast cancer cases, depending on the breast cancer subtype $[3,4,8,12]$. PIK3CA carrying a hotspot mutation exerts an oncogenic activity: it can transform primary fibroblasts in culture, induce anchorageindependent growth, and cause tumors in animals $[13,14]$. Apart from exons 9 and 20, PIK3CA has been recently shown to be also mutated frequently in other exons, as demonstrated by Cheung et al. in the case of endometrial cancer [15]. On the contrary, the PIK3R1 gene appears to play a tumor suppressor role because PI3K subunit $\mathrm{p} 85 \alpha(\mathrm{p} 85 \alpha)$ regulates and stabilizes p110 $\alpha \quad[7,16]$. PIK3R1 has also been recently found to be mutated in breast cancer, but with a considerably lower frequency (about 3\%) than PIK3CA [17]. The impact of its suppressor activity needs to be further described in breast cancer. It is noteworthy that other PI3K subunit encoding genes (PIK3CB, PIK3CD, PIK3CG, PIK3R2, PIK3R3) are altered with much lower frequency than PIK3CA and PIK3R1 [17]. Loss of PTEN expression, observed in about 20-30\% of cases, is known to be one of the most common tumor changes leading to PI3K pathway activation in breast cancer [4].

Discordant reports have been published concerning the prognostic role of PIK3CA mutations [4,18,19]. These mutations appear to be preferentially associated with more favorable clinicopathologic characteristics and more favorable outcome in breast cancer patients [3]. PIK3R1 underexpression might possibly lead to PI3K pathway activation and confer tumor development and progression in humans in a similar way to that observed in a mouse model of hepatocellular cancer [16].

In the present study, we explored the two genes encoding PI3K subunits and their role in PI3K pathway deregulation and patient survival. PIK3CA, PIK3R1 and AKT1 mRNA expression levels and mutations were studied. We also assessed mRNA expression levels of other genes involved in the PI3K pathway, namely EGFR, PDK1, PTEN, AKT1, AKT2, AKT3, GOLPH3, P7OS6K, and WEE1 to elucidate the pathway deregulations associated with changed PIK3CA and PIK3R1 states. PTEN and p85 protein expression were also assessed by immunohistochemistry.

\section{Methods}

\section{Patients and samples}

We analyzed 458 samples of unilateral invasive primary breast tumors excised from women at the Institut Curie/ Hôpital René Huguenin (Saint-Cloud, France) from 1978 to 2008 (Additional file 1: Table S1) where majority of the patients were diagnosed and treated between years
1990 and 2000 (67\%). All patients admitted to our institution before 2007 were informed that their tumor samples might be used for scientific purposes and they were given the opportunity to refuse the use of their samples. Since 2007, patients admitted to our institution also give their approval by signing an informed consent form. This study was approved by the local ethics committee (René Huguenin Hospital Breast Group). Patients (mean age: 61.7 years, range: $31-91)$ met the following criteria: primary unilateral non-metastatic breast carcinoma, with full clinical, histological and biological data; no radiotherapy or chemotherapy before surgery; and full follow-up at Institut Curie/Hôpital René Huguenin. Median follow-up was 8.6 years (range: 4.3 months to 28.9 years). One hundred and seventy patients developed metastases.

Samples were examined histologically and were considered suitable for this study when the proportion of tumor cells exceeded $70 \%$ with sufficient cellularity, as demonstrated by evaluation of tumor samples stained by hematoxylin and eosin. Immediately following surgery, tumor samples were placed in liquid nitrogen until RNA extraction and also stored as formalin-fixed paraffinembedded tumor tissue sample blocks for immunohistochemistry analysis.

Treatment consisted of modified radical mastectomy in 283 cases $(63.9 \%)$ and breast-conserving surgery plus locoregional radiotherapy in 160 cases (36.1\%). None of the ERBB2-positive patients was treated by anti-ERBB2 therapy. Clinical examinations were performed every 3 or 6 months for the first 5 years according to the prognostic risk of the patients, then yearly. Mammograms were done annually. Adjuvant therapy was administered to 358 patients, consisting of chemotherapy alone in 90 cases, hormone therapy alone in 175 cases and both treatments in 93 cases. The histological type and number of positive axillary nodes were established at the time of surgery. The malignancy of infiltrating carcinomas was scored with Bloom and Richardson's histoprognostic system.

Estrogen receptor (ER) and progesterone receptor (PR) status was determined at the protein level by using biochemical methods (dextran-coated charcoal method or enzyme immunoassay) until 1999 and then by immunohistochemistry. The cutoff for estrogen and progesterone receptor positivity was set at $15 \mathrm{fm} / \mathrm{mg}$ (dextran-coated charcoal or enzyme immunoassay) and $10 \%$ immunostained cells (immunohistochemistry). A tumor was considered ERBB2-positive by IHC when it scored 3+ with uniform intense membrane staining > 30\% of invasive tumor cells. Tumors scoring $2+$ were considered to be equivocal for ERBB2 protein expression and were tested by FISH for ERBB2 gene amplification. In all cases, the $\mathrm{ER} \alpha, \mathrm{PR}$ and ERBB2 status was also confirmed by real- 
time quantitative RT-PCR with cutoff levels based on previous studies comparing results of the these methods [20-23]. Based on HR (ER $\alpha$ and PR) and ERBB2 status, the 458 patients were subdivided into 4 subgroups as follows: HR- (ER- and PR-)/ERBB2- $(\mathrm{n}=69), \mathrm{HR}-(\mathrm{ER}-$ and $\mathrm{PR}-) / \mathrm{ERBB} 2+(\mathrm{n}=45), \mathrm{HR}+(\mathrm{ER}+$ or/and $\mathrm{PR}+) / \mathrm{ERBB} 2-$ $(\mathrm{n}=290)$ and $\mathrm{HR}+(\mathrm{ER}+$ or/and $\mathrm{PR}+) / \mathrm{ERBB} 2+(\mathrm{n}=54)$.

\section{RNA extraction}

Total RNA was extracted from breast tumor samples by using the acid-phenol guanidium method. The quantity of RNA was assessed by using an ND-1000 NanoDrop Spectrophotometer with its corresponding software (Thermo Fisher Scientific Inc., Wilmington, DE). RNA quality was determined by electrophoresis through agarose gel and staining with ethidium bromide. The $18 \mathrm{~S}$ and 28S RNA bands were visualized under ultraviolet light. DNA contamination was quantified by using a primer pair located in an intron of the gene encoding albumin (gene $A L B$ ). Only samples with a cycle threshold $(\mathrm{Ct})$ using these $A L B$ intron primers greater than 35 were used for subsequent analysis.

\section{Mutation screening}

PIK3CA mutations (exons 1, 2, 9, 20), PIK3R1 (exons 11-15) and $A K T 1$ (exon 4) were detected by sequencing of cDNA fragments obtained by RT-PCR amplification. Exons to be screened in the three genes were chosen following mutational frequency described at COSMIC: Catalogue Of Somatic Mutations In Cancer (cancer.sanger. ac.uk/). Screening by high-resolution melting curve analysis was performed on PIK3CA exons 1 and 2, AKT1 exon 4 and PIK3R1 exons 11 to 15 on a LightCycler 480 (Roche Diagnostics, Penzberg, Germany) using LCGreen Plus + Melting Dye fluorescence (Biotech, Idaho Technology Inc., Salt Lake City, UT). Details of the primers and PCR conditions are available on request. The amplified products were sequenced with the BigDye Terminator kit on an ABI Prism 3130 automatic DNA sequencer (Applied Biosystems, Courtaboeuf, France) with detection sensitivity of $5 \%$ mutated cells, and the sequences were compared with the corresponding cDNA reference sequences (PIK3CA NM_006218, PIK3R1 NM_181523, AKT1 NM_005163). All detected mutations were confirmed in the second independent run of sample testing.

\section{Real-time quantitative RT-PCR}

RT-PCR was applied to the selected genes and to TBP (NM_003194) as endogenous mRNA control. Primers are listed in Additional file 2: Table S2. PCR conditions are available on request. The RT-PCR protocol using the SYBR Green Master Mix kit on the ABI Prism 7900 Sequence Detection System (Perkin-Elmer Applied
Biosystems, Foster City, CA) is described in detail elsewhere [20]. The relative mRNA expression level of each gene, expressed as the $\mathrm{N}$-fold difference in target gene expression relative to the TBP gene, and termed "Ntarget", was calculated as Ntarget $=2^{\Delta \text { Ctsample }}$. The value of the cycle threshold $(\Delta \mathrm{Ct})$ of a given sample was determined by subtracting the average $C t$ value of the target gene from the average $\mathrm{Ct}$ value of the TBP gene. The Ntarget values of the samples were subsequently normalized so that the median Ntarget value of normal breast samples was 1 . Cut-offs for normalized values $\leq 0.5$ and $\geq 2.0$ were used to determine gene underexpression and overexpression, respectively.

\section{Immunohistochemistry}

PTEN and p85 protein expression levels were assessed by immunohistochemistry staining on tumor sections from formalin-fixed paraffin-embedded blocks. Indirect immunoperoxidase staining was performed using mouse monoclonal antibody directed against human PTEN protein (Dako, Glostrup, Denmark) and rabbit polyclonal antibody directed against human p85 protein (Signalway Antibody, Baltimore, Maryland). The localization and intensity of staining were assessed by two independent pathologists blinded to real-time RT-PCR results.

Both antibodies were used at a 1/50 dilution. The immunohistochemical procedure was performed as described below, using a water bath antigen-retrieval technique in each case. Sections were mounted on precoated slides (Dako, Glostrup, Denmark) and allowed to dry at $50^{\circ} \mathrm{C}$ overnight. Sections were then dewaxed in xylene and hydrated by graded dilutions of ethanol. Endogenous activity was blocked with $1 \%$ hydrogen peroxide for $15 \mathrm{~min}$. Sections were then immersed in a heat-resistant plastic box containing $10 \mathrm{ml}$ of pH 9.0 citrate buffer and processed in the water bath for $40 \mathrm{~min}$. Sections were then allowed to cool to room temperature for 20 min before rinsing in $\mathrm{H}_{2} \mathrm{O}$. The blocking reagent was poured off and the primary antibodies were left for $25 \mathrm{~min}$. A standard avidin-biotin-peroxidase complex (LSAB) method was used to reveal the antibody-antigen reaction (Dako, Glostrup, Denmark). Autostainer link 48 was used for the staining process (Dako, Glostrup, Denmark).

Normal ductal epithelial cells showed a positive cytoplasmic immunostaining, whereas PTEN expression in tumor cells varied with cytoplasmic and/or nuclear staining. A semi-quantitative intensity score was performed (score 0: negative staining, score 1: weak cytoplasmic staining, score 2: moderate cytoplasmic staining, score 3: strong and diffuse cytoplasmic staining). Positive immunohistochemical reactions were defined as a brown cytoplasmic staining for p85. A semi-quantitative intensity scale ranging from 0 for no staining to $3+$ for the most 
intense staining was used by comparing neoplastic cells to adjacent breast cells belonging to normal terminal ductulo-lobular units. p85 underexpression was defined by an IHC score 0 , p 85 normal expression by an IHC score 1, and p85 overexpression by an IHC score $2+$ and $3+$.

\section{Statistical analysis}

Relationships between tumor changes (expressed as mutational or expression status) and clinical, histological and biological parameters were estimated with the $\mathrm{Chi}^{2}$ test. A level of significance was set at 5\%. Metastasis-free survival (MFS) was determined as the interval between diagnosis and detection of the first metastasis. Survival distributions were estimated by the Kaplan-Meier method [24], and the significance of differences between survival rates was ascertained with the log-rank test [25]. Cox's proportional hazards regression model [26] was used to assess prognostic significance in multivariate analysis.

\section{Results \\ PIK3CA, PIK3R1 and AKT1 mutational analysis}

The present study extends our previously published data describing the positive effect of PIK3CA exon 9 and 20 mutations on breast cancer patient survival [12]. In the present study, PIK3CA mutations were additionally assessed in exons 1 and 2. PIK3CA mutations were identified in 151 (33.0\%) of the 458 samples, in line with previous studies in which PIK3CA mutations were found in 10 to $40 \%$ of breast cancer cases $[3,4,8]$. Sixty-three tumors showed PIK3CA mutations located in exon 9, 85 tumors showed mutations in exon 20, and one tumor showed mutations in both exon 9 and exon 20. Five mutations were found in exon 1, including two cases with 3 nucleotide deletions (c.305_307del and c.328_330del). Three other mutated tumors showed point mutations (R115L in one case and R108H in two cases). Two tumors showed mutations in exon 2 (both G118D). Point mutations in exons 1 and 2 were always found in cases mutated in either exon 9 or exon 20, but the two tumors with deletions did not present any additional PIK3CA mutations in other exons. Breast cancer subgroup analysis demonstrated PIK3CA mutations with the lowest frequency $(10 / 69 ; 14.5 \%)$ in HR-/ERBB2- tumors and the highest frequency $(118 / 290 ; 40.7 \%)$ in HR+/ERBB2- tumors, while an intermediate frequency of PIK3CA mutations was observed in HR-/ERBB2+ and HR+/ERBB2+ tumors $(9 / 45 ; 20.0 \%$ and $14 / 54 ; 25.9 \%$, respectively).

PIK3R1 mutations were screened in exons 11-15 and were present in $10(2.2 \%)$ of the 454 available samples (Additional file 3: Table S3). Seven cases of deletions of 3 -nucleotide multiples were observed in exons 11 and 13 (in the area between nucleotides 1345-1368 and
1701-1743, respectively), 2 cases of duplications of 3nucleotide multiples were observed in exon 13 (in the area between nucleotides 1650-1723) and 1 case of point mutations were observed in exon 15 (c.1925G > T). It is noteworthy that we found also c.1590G > A giving the AAG $\rightarrow$ AAA (Lys) nucleotide substitution located in exon 13 that is probably a polymorphism with no amino acid change. PIK3R1 mutations were found in only 1 of the 151 PIK3CA-mutated cases and in 10 of the 297 PIK3CA wild-type cases. The low frequency of PIK3R1 mutations did not allow any further statistical analysis concerning a possible association between PIK3R1 mutations and clinical, histological and biological parameters.

AKT1 mutation (E17K) was found in 15 (3.3\%) of the 457 available samples. $A K T 1$ mutations were found in only 1 of the 161 PIK3CA/PIK3R1-mutated cases and 14 of the 297 PIK3CA/PIK3R1 wild-type cases and tended therefore to mutual exclusivity with $P I 3 K$ mutations $(\mathrm{p}=0.019)$.

Altogether, we observed PIK3CA and/or PIK3R1 and/ or $A K T 1$ mutations in 174/454 (38.3\%) breast cancer tumors. Breast cancer subgroup analysis demonstrated mutation of at least one of the three genes with the highest frequency in HR+/ERBB2- tumors (133/289; $46.0 \%)$. The other 3 breast cancer subtypes showed a lower frequency of these mutations: $\mathrm{HR}+/ \mathrm{ERBB} 2+$ in $15 / 54$ (27.8\%), HR-/ERBB2+ in 10/43 (23.3\%) and HR-/ERBB2- in 16/68 (23.5\%).

\section{mRNA expression}

The PIK3CA, PIK3R1 and AKT1 mRNA expression levels were assessed in the whole series of 458 samples. PIK3R1 underexpression was found in 283 (61.8\%) cases, indicating a relevant tumor alteration occurring in the majority of tumor samples (Table 1). Moreover, when assessing breast cancer subgroups, PIK3R1 was predominantly underexpressed in HR-/ERBB2- and HR-/ERBB2+ tumors ( $\mathrm{p}<0.0000001$ ) (Table 2), while PIK3CA was deregulated in only a minority of tumor samples: overexpressed in 18 (3.9\%) and underexpressed in 40 (8.7\%) cases (Table 1). PIK3CA expression did not vary significantly between the four breast cancer subgroups based on hormone and ERBB2 receptor status (Table 2). Expression levels of PIK3CA, the oncogene bearing the highest number of mutations in breast cancer, were therefore mostly stable in breast cancer subgroups indicating that mutations constituted the main tumor change affecting PIK3CA. These results show that changes of expression of PIK3R1 but not PIK3CA play a role in breast cancer, specifically in hormone receptor-negative cases.

$A K T 1$ overexpression was present in 116 (25.3\%) of the 458 available samples, mostly in HR-/ERBB2+ and $\mathrm{HR}+/$ ERBB2 + tumors $(\mathrm{p}=0.00019)$ (Table 2). Seven of 
Table 1 Gene mRNA levels in $\mathbf{4 5 8}$ breast tumors

\begin{tabular}{|c|c|c|c|c|c|c|c|}
\hline Genes & $\begin{array}{l}\text { Median Ct of } \\
\text { normal breast } \\
\text { tissue }(n=10)\end{array}$ & $\begin{array}{l}\text { Normal breast } \\
\text { tissue }(n=10)\end{array}$ & Breast tumors $n=458$ & $\begin{array}{c}\text { Percentage of } \\
\text { underexpressed } \\
\text { tumors } \\
\text { (Ntarget } \leq 0.5 \text { ) }\end{array}$ & $\begin{array}{c}\text { Percentage } \\
\text { of normal } \\
\text { expressed } \\
\text { tumors }\end{array}$ & $\begin{array}{c}\text { Percentage of } \\
\text { overexpressed } \\
\text { tumors } \\
(\text { Ntarget } \geq 2 \text { ) }\end{array}$ & $\begin{array}{c}\text { Percentage of } \\
\text { overexpressed } \\
\text { tumors } \\
(\text { Ntarget } \geq 5)\end{array}$ \\
\hline$\overline{E G F R}$ & $30.2(29.3-31.5)^{a}$ & $1.0(0.7-1.3)^{b}$ & $0.2(0.0-112.9)^{b}$ & $84.9 \%^{c}$ & $13.3 \%^{\mathrm{c}}$ & $1.8 \%^{\mathrm{c}}$ & $0.7 \%^{c}$ \\
\hline PIK3CA & $29.7(28.4-31.0)$ & $1.0(0.7-1.3)$ & $0.9(0.2-33.4)$ & $8.7 \%$ & $87.4 \%$ & $3.9 \%$ & $0.7 \%$ \\
\hline PIK3R1 & $26.8(25.8-28.1)$ & $1.0(0.7-1.5)$ & $0.4(0.0-5.2)$ & $61.8 \%$ & $36.0 \%$ & $2.2 \%$ & $0.2 \%$ \\
\hline PDK1 & $31.8(29.7-33.5)$ & $1.0(0.5-1.9)$ & $1.0(0.0-14.7)$ & $13.3 \%$ & $69.0 \%$ & $17.7 \%$ & $2.2 \%$ \\
\hline PTEN & $26.4(25.3-31.3)$ & $1.1(0.7-2.0)$ & $0.8(0.1-9.0)$ & $17.0 \%$ & $81.0 \%$ & $2.0 \%$ & $0.4 \%$ \\
\hline AKT1 & $28.7(27.5-30.1)$ & $1.0(0.7-1.5)$ & $1.5(0.0-11.1)$ & $1.3 \%$ & $73.4 \%$ & $25.3 \%$ & $2.8 \%$ \\
\hline AKT2 & $26.7(25.4-29.7)$ & $1.0(0.7-2.0)$ & $1.7(0.5-12.2)^{d}$ & $0.0 \%$ & $64.0 \%$ & $36.0 \%$ & $3.3 \%$ \\
\hline AKT3 & $26.0(23.8-28.4)$ & $1.0(0.6-1.9)$ & $0.4(0.0-7.5)^{d}$ & $67.1 \%$ & $31.1 \%$ & $1.8 \%$ & $0.2 \%$ \\
\hline GOLPH3 & $27.9(26.4-29.0)$ & $1.0(0.8-1.6)$ & $1.4(0.3-6.7)$ & $0.7 \%$ & $79.9 \%$ & $19.4 \%$ & $0.9 \%$ \\
\hline P70S6K & $31.2(29.9-32.7)$ & $1.0(0.7-1.8)$ & $1.2(0.0-19.6)$ & $2.2 \%$ & $79.7 \%$ & $18.1 \%$ & $3.7 \%$ \\
\hline WEE1 & $28.4(26.1-29.8)$ & $1.0(0.5-1.6)$ & $0.8(0.2-6.9)$ & $18.3 \%$ & $77.3 \%$ & $4.4 \%$ & $0.2 \%$ \\
\hline
\end{tabular}

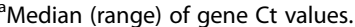

${ }^{\mathrm{b}}$ Median (range) of gene mRNA levels; the mRNA values of the samples were normalized so that the median of the 10 normal breast tissue mRNA values was 1.

cPercentages of underexpressing, normal and overexpressing tumors using cut-offs of Ntarget $\leq 0.5$ and Ntarget $\geq 2$.

${ }^{\mathrm{d}}$ Data available in 456 samples.

The bold numbers stress important finding or overall characterisation of a group or p-value.

the $15 A K T 1$ mutated tumors also showed increased AKT1 expression. However, AKT1 mutation and expression status as well as expression changes in other genes of the PI3K/AKT pathway did not show any statistically significant association (data not shown) possibly because of the small number of $A K T 1$ mutated cases.

mRNA expression levels of other genes involved in the PI3K/AKT pathway were also evaluated., i.e. EGFR, PDK1, PTEN, AKT2 and 3, GOLPH3, P7OS6K, and WEE1 (Table 1). Markedly high expression that might be caused by gene amplification was observed only in low frequency $(<4 \%)$ of tumors as shows the last colon in the Table 1. PTEN underexpression was significantly mutually exclusive with PIK3CA, PIK3R1 and AKT1 mutations ( $\mathrm{p}=0.00016)$, as it was observed in only one $A K T 1$ mutated tumor and 14 PIK3CA mutated tumors. Expression levels were also compared in the four breast cancer subgroups as shown in Table 2. Interestingly, gene expressions were deregulated in different ways in the 4 subgroups. EGFR underexpression was demonstrated in all subgroups, as previously published [27]. P7OS6K and AKT1 was predominantly overexpressed in ERBB2+ tumors ( $\mathrm{p}<0.0000001$ and 0.00019 , respectively). This increased expression of these two genes might be linked to the PI3K/AKT pathway activated by ERBB2 overexpression. On the other hand, expression changes in HR-/ERBB2- tumors might indicate downstream activation of the pathway occurring despite the negativity of ERBB2. The 4 molecular subgroups of breast cancer therefore appeared to undergo distinct changes at the levels of mRNA expression of the genes involved in the PI3K/AKT pathway. These data would benefit from confirmation at protein level (both quantity and activity).

The next step of analysis focused on PI3K constituents, specifically PIK3R1 expression and PIK3CA mutations in relation to expression levels of the other genes evaluated. Tumors characterized by PIK3R1 underexpression were associated with deregulation of other genes involved in the PI3K/AKT pathway (Table 3). PIK3R1 underexpression was negatively associated with PIK3CA mutations $(\mathrm{p}=0.00097)$ and these two parameters were therefore predominantly mutually exclusive. In contrast to PIK3R1, deregulation of the expression of genes involved in the PI3K/AKT pathway was almost exclusively associated with PIK3CA wild-type tumors (Table 4).

\section{Immunohistochemistry}

Alteration of $\mathrm{p} 85$ (encoded by PIK3R1) and PTEN expression was also verified at the protein level by immunohistochemistry in randomly selected samples with low and high mRNA expression. In both cases, samples showing decreased mRNA expression (5 PIK3R1 underexpressed- and 5 PTEN underexpressed-tumors) also presented low immunohistochemical staining intensity. Similarly, samples showing normal mRNA expression (7 PIK3R1 expressing and 8 PTEN expressing tumors) presented strong immunohistochemical staining intensity. The only exceptions were two samples stained for PTEN (one showing low mRNA expression and more intense immunohistochemistry staining, the other showing opposite features). A good match (23/25 samples tested) was therefore obtained between mRNA and protein expression status for both PIK3R1 and PTEN (Figure 1). These results 
Table 2 Genes mRNA levels in the 4 breast tumor subtypes

\begin{tabular}{|c|c|c|c|c|c|c|}
\hline & All tumors & & Tum & ubtypes & & \\
\hline & & HR-ERBB2- & HR-ERBB2+ & $H R+E R B B 2-$ & $\overline{H R+E R B B 2+}$ & $P$-value $e^{a}$ \\
\hline & $n=458$ & $n=69$ & $n=45$ & $n=290$ & $n=54$ & \\
\hline PIK3CA values: median [range] & $0.9(0.2-33.4)$ & $0.9(0.3-33.4)$ & $0.7(0.3-1.7)$ & $0.9(0.2-5.9)$ & $1.0(0.4-5.6)$ & NS \\
\hline Underexpressed tumors (\%) & $40(8.7)$ & $6(8.7)$ & $5(11.1)$ & $25(8.6)$ & $4(7.4)$ & \\
\hline Non-underexpressed tumors (\%) & $418(91.3)$ & $63(91.3)$ & $40(88.9)$ & $265(91.4)$ & $50(92.6)$ & \\
\hline PIK3R1 values: median [range] & $0.4(0.0-5.2)$ & $0.2(0.0-2.2)$ & $0.3(0.1-1.5)$ & $0.5(0.1-4.4)$ & $0.4(0.1-5.2)$ & $<0.0000001$ \\
\hline Underexpressed tumors (\%) & $283(61.8)$ & $61(88.4)$ & $40(88.9)$ & $150(51.7)$ & $32(59.3)$ & \\
\hline Non-underexpressed tumors (\%) & $175(38.2)$ & $8(11.6)$ & $5(11.1)$ & $140(48.3)$ & $22(40.7)$ & \\
\hline PDK1 values: median [range] & $1.0(0.0-14.7)$ & $2.4(0.5-14.7)$ & $1.7(0.4-6.2)$ & $0.9(0.0-3.3)$ & $0.9(0.1-2.4)$ & $<0.0000001$ \\
\hline Underexpressed tumors (\%) & $61(13.3)$ & 0 & $1(2.2)$ & $51(7.9)$ & $9(16.6)$ & \\
\hline Normally expressed tumors (\%) & $316(69.0)$ & $25(36.2)$ & $27(60.0)$ & $221(90.0)$ & $43(79.6)$ & \\
\hline Overexpressed tumors (\%) & $81(17.7)$ & $44(63.8)$ & $17(37.8)$ & $18(2.1)$ & $2(3.7)$ & \\
\hline PTEN values: median [range] & $0.8(0.1-9.0)$ & $0.6(0.1-1.5)$ & $0.8(0.3-1.9)$ & $0.8(0.1-9.0)$ & $0.9(0.4-3.3)$ & 0.0000066 \\
\hline Underexpressed tumors (\%) & $78(17.0)$ & $27(39.1)$ & $6(13.3)$ & 39 (13.4) & $6(11.1)$ & \\
\hline Non-underexpressed tumors (\%) & $380(83.0)$ & $42(60.9)$ & $39(86.7)$ & $251(86.6)$ & $48(88.9)$ & \\
\hline AKT1 values: median [range] & $1.5(0.0-11.1)$ & $1.1(0.0-11.1)$ & $2.0(0.6-10.0)$ & $1.4(0.4-6.1)$ & $1.8(0.6-9.9)$ & 0.00019 \\
\hline Non-overexpressed tumors (\%) & $342(74.7)$ & $55(79.7)$ & $24(53.3)$ & $230(79.3)$ & $33(61.1)$ & \\
\hline Overexpressed tumors (\%) & $116(25.3)$ & $14(20.3)$ & $21(46.7)$ & $60(20.7)$ & $21(38.9)$ & \\
\hline AKT2 values: median [range] $]^{\mathrm{b}}$ & $1.7(0.5-12.2)$ & $1.7(0.7-12.2)$ & $1.4(0.8-8.7)$ & $1.8(0.5-10.6)$ & $1.8(0.5-7.0)$ & 0.0097 \\
\hline Non-overexpressed tumors (\%) & $293(64.3)$ & $46(67.6)$ & 38 (84.4) & $180(62.3)$ & $29(53.7)$ & \\
\hline Overexpressed tumors (\%) & $163(35.7)$ & $22(32.4)$ & $7(15.6)$ & $109(37.7)$ & $25(46.3)$ & \\
\hline AKT3 values: median [range] $]^{\mathrm{b}}$ & $0.4(0.0-7.5)$ & $0.5(0.0-2.2)$ & $0.3(0.1-0.9)$ & $0.4(0.0-7.5)$ & $0.4(0.1-2.3)$ & NS \\
\hline Underexpressed tumors (\%) & $306(67.1)$ & $38(55.9)$ & $32(71.1)$ & $198(68.5)$ & $38(70.4)$ & \\
\hline Non-underexpressed tumors (\%) & $150(32.9)$ & $30(44.1)$ & $13(28.9)$ & $91(31.5)$ & $16(29.6)$ & \\
\hline GOLPH3 values: median [range] & $1.4(0.3-6.7)$ & $1.2(0.6-3.3)$ & $1.4(0.7-5.0)$ & $1.3(0.3-6.7)$ & $1.7(0.8-5.4)$ & NS \\
\hline Non-overexpressed tumors (\%) & $369(80.6)$ & $54(78.3)$ & $36(80.0)$ & $241(83.1)$ & $38(70.4)$ & \\
\hline Overexpressed tumors (\%) & $89(19.4)$ & $15(21.7)$ & $9(20.0)$ & 49 (16.9) & $16(29.6)$ & \\
\hline P70S6K values: median [range] & $1.2(0.0-19.6)$ & $1.0(0.0-5.4)$ & $1.9(0.6-9.9)$ & $1.2(0.3-8.0)$ & $1.4(0.4-19.6)$ & $<0.0000001$ \\
\hline Non-overexpressed tumors (\%) & $375(81.9)$ & $64(92.8)$ & $24(53.3)$ & $250(86.2)$ & $37(68.5)$ & \\
\hline Overexpressed tumors (\%) & $83(18.1)$ & $5(7.2)$ & $21(46.7)$ & $40(13.8)$ & $17(31.5)$ & \\
\hline WEE1 values: median [range] & $0.8(0.2-6.9)$ & $0.7(0.2-6.9)$ & $0.9(0.3-2.8)$ & $0.8(0.2-3.9)$ & $0.8(0.3-4.1)$ & 0.0014 \\
\hline Underexpressed tumors (\%) & $84(18.3)$ & $24(34.8)$ & $6(13.3)$ & $43(14.8)$ & $11(20.4)$ & \\
\hline Non-underexpressed tumors (\%) & $374(81.7)$ & $45(65.2)$ & $39(86.7)$ & 247 (85.2) & $43(79.6)$ & \\
\hline
\end{tabular}

${ }^{\mathrm{a}} \mathrm{Chi}^{2}$ test of independency in contingency tables (tumor subtype vs. gene expression). NS: not significant.

${ }^{b}$ Data available in 456 samples.

The bold numbers stress important finding or overall characterisation of a group or $p$-value.

suggest that the regulation of p85 (and PTEN) expression is mainly transcriptional.

\section{Survival analysis}

Survival curves were compared to assess the possible impact of these expression changes and mutations on patient outcome. Additional file 4: Table S4 summarizes survival analysis performed on the overall patient series. Patients presenting any of the mutations assessed in this study (PIK3CA, PIK3R1 or AKT1) had a significantly better MFS ( $\mathrm{p}=0.024)$. Among the 11 genes studied, only PIK3CA mutations and PIK3R1 underexpression, as separate markers, were associated with MFS and had opposite effects on patient survival: PIK3CA mutation was associated with better MFS and PIK3R1 underexpression was associated with poorer MFS $(\mathrm{p}=0.016$ and $\mathrm{p}=0.00028$, respectively). PIK3R1 underexpression was associated with histological grade 3 status and an increased rate of positive axillary lymph nodes ( $\mathrm{p}<0.0000001$ and $\mathrm{p}=0.013$, respectively). HR- and 
Table 3 Comparison of PIK3R1 expression status and alterations of other genes of interest

\begin{tabular}{|c|c|c|c|c|}
\hline & \multirow[b]{2}{*}{ Total population (\%) } & \multicolumn{2}{|c|}{ Number of patients (\%) } & \multirow[b]{2}{*}{$P$-value ${ }^{a}$} \\
\hline & & PIK3R1 underexpression & $P I K 3 R 1$ non-underexpression & \\
\hline Total & $458(100.0)$ & $283(61.8)$ & $175(38.2)$ & \\
\hline EGFR values: median [range] & $0.2(0.0-112.9)$ & $0.1(0.0-7.3)$ & $0.2(0.0-112.9)$ & \\
\hline Underexpressed tumors (\%) & $389(84.9)$ & $250(88.3)$ & $139(79.4)$ & 0.0096 \\
\hline Non-underexpressed tumors (\%) & $69(15.1)$ & $33(11.7)$ & $36(20.6)$ & \\
\hline PDK1 values: median [range] & $1.0(0.0-14.7)$ & $1.2(0.1-14.7)$ & $0.9(0.0-6.2)$ & \\
\hline Underexpressed tumors (\%) & $61(13.3)$ & $26(9.2)$ & $35(20.0)$ & 0.000004 \\
\hline Normally expressed tumors (\%) & $316(69.0)$ & $189(66.8)$ & $127(72.6)$ & \\
\hline Overexpressed tumors (\%) & $81(17.7)$ & $68(24.0)$ & $13(7.4)$ & \\
\hline AKT1 values: median [range] & $1.5(0.0-11.1)$ & $1.4(0.4-10.0)$ & $1.6(0.0-11.1)$ & \\
\hline Non-overexpressed tumors (\%) & $342(74.7)$ & $216(76.3)$ & $126(72.0)$ & NS \\
\hline Overexpressed tumors (\%) & $116(25.3)$ & $67(23.7)$ & $49(28.0)$ & \\
\hline AKT2 values: median [range] & $1.0(0.7-2.3)$ & $1.6(0.5-10.6)$ & $1.8(0.5-12.2)$ & \\
\hline Non-overexpressed tumors (\%) & $293(64.3)$ & $189(67.0)$ & $104(59.8)$ & NS \\
\hline Overexpressed tumors (\%) & $163(35.7)$ & $93(33.0)$ & $70(40.2)$ & \\
\hline AKT3 values: median [range] ${ }^{b}$ & $1.0(0.4-1.9)$ & $0.3(0.0-2.4)$ & $0.5(0.1-7.5)$ & \\
\hline Underexpressed tumors (\%) & $306(67.1)$ & $215(76.2)$ & $91(52.3)$ & 0.00000013 \\
\hline Non-underexpressed tumors (\%) & $150(32.9)$ & $67(23.8)$ & $83(47.7)$ & \\
\hline GOLPH3 values: median [range] & $1.4(0.3-6.7)$ & $1.3(0.3-5.2)$ & $1.7(0.7-6.7)$ & \\
\hline Non-overexpressed tumors (\%) & $369(80.6)$ & $242(85.5)$ & $127(72.6)$ & 0.00067 \\
\hline Overexpressed tumors (\%) & $89(19.4)$ & $41(14.5)$ & $48(27.4)$ & \\
\hline P70S6K values: median [range] & $1.2(0.0-19.6)$ & $1.2(0.4-19.6)$ & $1.2(0.0-8.9)$ & \\
\hline Non-overexpressed tumors (\%) & $375(81.9)$ & $226(79.9)$ & $149(85.1)$ & NS \\
\hline Overexpressed tumors (\%) & $83(18.1)$ & $57(20.1)$ & $26(14.9)$ & \\
\hline WEE1 values: median [range] & $0.8(0.2-6.9)$ & $0.7(0.2-4.1)$ & $0.9(0.2-6.9)$ & \\
\hline Underexpressed tumors (\%) & $84(18.3)$ & $68(24.0)$ & $16(9.1)$ & 0.000063 \\
\hline Non-underexpressed tumors (\%) & $374(81.7)$ & $215(76.0)$ & $159(90.9)$ & \\
\hline PTEN values: median [range] & $0.8(0.1-9.0)$ & $0.7(0.1-9.0)$ & $1.0(0.4-5.8)$ & \\
\hline Underexpressed tumors (\%) & $78(17.0)$ & $71(25.1)$ & $7(4.0)$ & $<0.0000001$ \\
\hline Non-underexpressed tumors (\%) & $380(83.0)$ & $212(74.9)$ & $168(96.0)$ & \\
\hline \multicolumn{5}{|l|}{ PIK3CA } \\
\hline Wild-type (\%) & $307(67.0)$ & $205(72.4)$ & $102(58.3)$ & 0.0017 \\
\hline Mutation (\%) & $151(33.0)$ & 78 (27.6) & $73(41.7)$ & \\
\hline \multicolumn{5}{|l|}{$P I K 3 R 1^{C}$} \\
\hline Wild-type (\%) & $444(97.8)$ & $276(98.6)$ & 168 (96.6) & NS \\
\hline Mutation (\%) & $10(2.2)$ & $4(1.4)$ & $6(3.4)$ & \\
\hline \multicolumn{5}{|l|}{$A K T 1^{d}$} \\
\hline Wild-type (\%) & $442(96.7)$ & $272(96.5)$ & $170(97.1)$ & NS \\
\hline Mutation (\%) & $15(3.3)$ & $10(3.5)$ & $5(2.9)$ & \\
\hline
\end{tabular}

${ }^{\mathrm{a} C h i}{ }^{2}$ test. NS: not significant.

${ }^{b}$ Data available in 456 samples.

'Data available in 454 samples.

${ }^{\mathrm{d} D a t a}$ available in 457 samples.

The bold numbers stress important finding or overall characterisation of a group or $\mathrm{p}$-value. 
Table 4 Comparison of PIK3CA mutational status and alterations in other genes of interest

\begin{tabular}{|c|c|c|c|c|}
\hline & \multirow[b]{2}{*}{ Total population (\%) } & \multicolumn{2}{|c|}{ Number of patients (\%) } & \multirow[b]{2}{*}{$P$-value ${ }^{a}$} \\
\hline & & PIK3CA wild-type & PIK3CA-mutated & \\
\hline Total & $458(100.0)$ & $307(67.0)$ & $151(33.0)$ & \\
\hline EGFR values: median [range] & $0.2(0.0-112.9)$ & $0.2(0.0-112.9)$ & $0.2(0.0-7.3)$ & \\
\hline Underexpressed tumors (\%) & $389(84.9)$ & $256(83.4)$ & $133(88.1)$ & NS \\
\hline Non-underexpressed tumors (\%) & $69(15.1)$ & $51(16.6)$ & $18(11.9)$ & \\
\hline PIK3R1 values: median [range] & $0.4(0.0-5.2)$ & $0.3(0.0-4.4)$ & $0.5(0.1-5.2)$ & \\
\hline Underexpressed tumors (\%) & $283(61.8)$ & $205(66.8)$ & $78(51.7)$ & 0.0017 \\
\hline Non-underexpressed tumors (\%) & $175(38.2)$ & $102(33.2)$ & $73(48.3)$ & \\
\hline PDK1 values: median [range] & $1.0(0.0-14.7)$ & $1.1(0.0-14.7)$ & $0.8(0.1-4.5)$ & \\
\hline Underexpressed tumors (\%) & $61(13.3)$ & $35(11.4)$ & $26(17.2)$ & 0.0011 \\
\hline Normally expressed tumors (\%) & $316(69.0)$ & $204(66.5)$ & $112(74.2)$ & \\
\hline Overexpressed tumors (\%) & $81(17.7)$ & $68(22.1)$ & $13(8.6)$ & \\
\hline PTEN values: median [range] & $0.8(0.1-9.0)$ & $0.8(0.1-5.8)$ & $0.9(0.1-9.0)$ & \\
\hline Underexpressed tumors (\%) & $78(17.0)$ & $64(20.8)$ & $14(9.3)$ & 0.0019 \\
\hline Non-underexpressed tumors (\%) & $380(83.0)$ & $243(79.2)$ & $137(90.7)$ & \\
\hline AKT1 values: median [range] & $1.5(0.0-11.1)$ & $1.5(0.0-11.1)$ & $1.5(0.4-9.9)$ & \\
\hline Non-overexpressed tumors (\%) & $342(74.7)$ & $230(74.9)$ & $112(74.2)$ & NS \\
\hline Overexpressed tumors (\%) & $116(25.3)$ & $77(25.1)$ & $39(25.8)$ & \\
\hline AKT2 values: median [range] $]^{b}$ & $1.0(0.7-2.3)$ & $1.7(0.5-12.2)$ & $1.6(0.5-10.6)$ & \\
\hline Non-overexpressed tumors (\%) & $293(64.3)$ & $190(62.3)$ & $103(68.2)$ & NS \\
\hline Overexpressed tumors (\%) & $163(35.7)$ & $115(37.7)$ & $48(31.8)$ & \\
\hline AKT3 values: median [range] ${ }^{b}$ & $1.0(0.4-1.9)$ & $0.4(0.0-3.6)$ & $0.4(0.1-7.5)$ & \\
\hline Underexpressed tumors (\%) & $306(67.1)$ & $206(67.5)$ & $100(66.2)$ & NS \\
\hline Non-underexpressed tumors (\%) & $150(32.9)$ & $99(32.5)$ & $51(33.8)$ & \\
\hline GOLPH3 values: median [range] & $1.4(0.3-6.7)$ & $1.4(0.5-6.7)$ & $1.3(0.3-5.4)$ & \\
\hline Non-overexpressed tumors (\%) & $369(80.6)$ & $242(78.8)$ & $127(84.1)$ & NS \\
\hline Overexpressed tumors (\%) & $89(19.4)$ & $65(21.2)$ & $24(15.9)$ & \\
\hline P70S6K values: median [range] & $1.2(0.0-19.6)$ & $1.2(0.0-19.6)$ & $1.1(0.4-8.0)$ & \\
\hline Non-overexpressed tumors (\%) & $375(81.9)$ & $233(75.9)$ & $142(94.0)$ & 0.0000022 \\
\hline Overexpressed tumors (\%) & $83(18.1)$ & $74(24.1)$ & $9(6.0)$ & \\
\hline WEE1 values: median [range] & $0.8(0.2-6.9)$ & $0.8(0.2-6.9)$ & $0.7(0.3-3.4)$ & \\
\hline Underexpressed tumors (\%) & $84(18.3)$ & $61(19.9)$ & $23(15.2)$ & NS \\
\hline Non-underexpressed tumors (\%) & $374(81.7)$ & $246(80.1)$ & $128(84.8)$ & \\
\hline \multicolumn{5}{|l|}{$P I K 3 R 1^{c}$} \\
\hline Wild-type (\%) & $444(97.8)$ & $294(97.0)$ & $150(99.3)$ & NS \\
\hline Mutation (\%) & $10(2.2)$ & $9(3.0)$ & $1(0.7)$ & \\
\hline \multicolumn{5}{|l|}{$A K T 1^{d}$} \\
\hline Wild-type (\%) & $442(96.7)$ & $292(95.4)$ & $150(99.3)$ & NS \\
\hline Mutation (\%) & $15(3.3)$ & $14(4.6)$ & $1(0.7)$ & \\
\hline
\end{tabular}

${ }^{\mathrm{a} C h i}{ }^{2}$ test. NS: not significant.

${ }^{b}$ Data available in 456 samples.

'Data available in 454 samples.

dData available in 457 samples.

The bold numbers stress important finding or overall characterisation of a group or $\mathrm{p}$-value. 


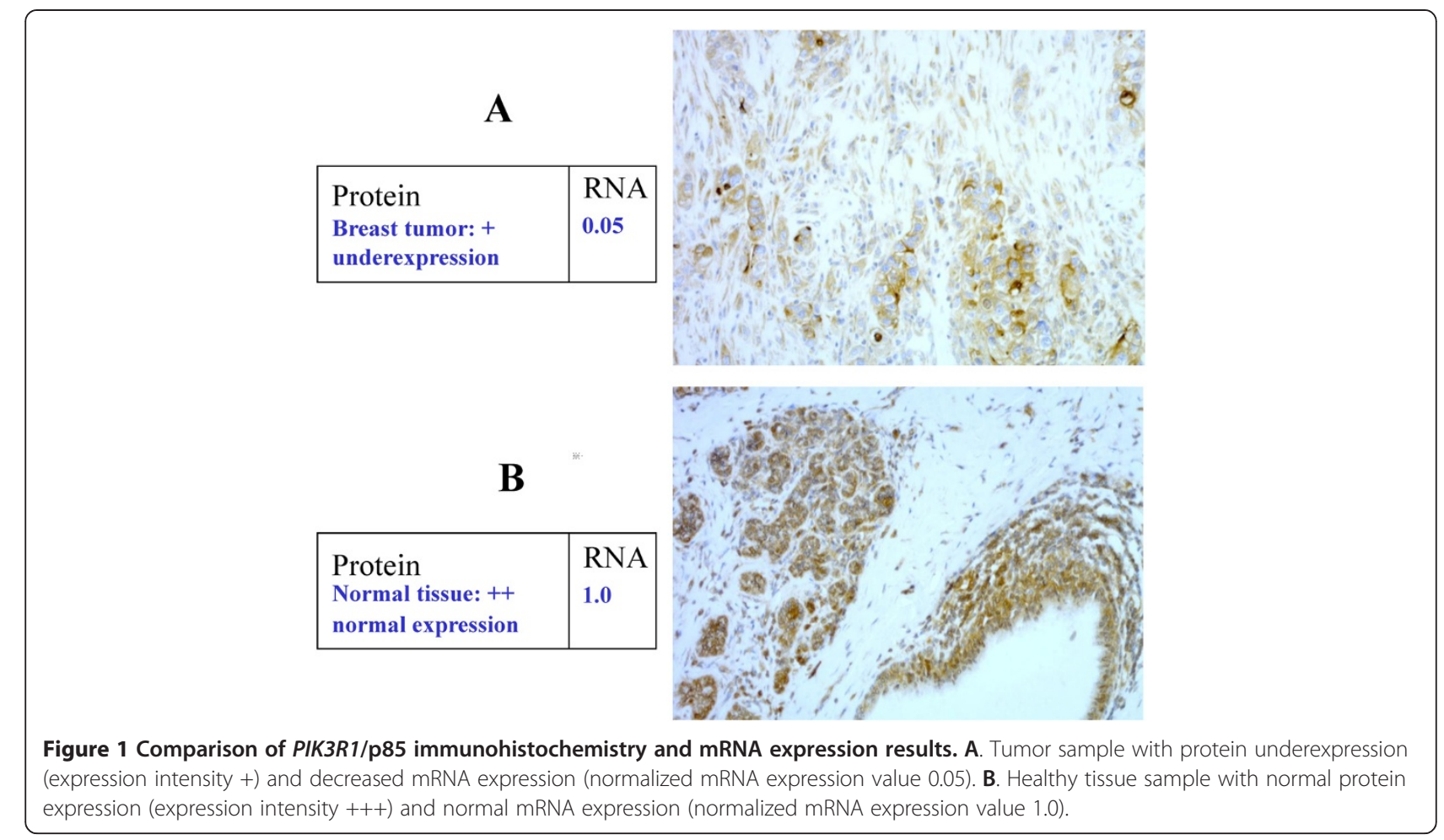

ERBB2+ tumors were also more likely to present PIK3R1 underexpression $(\mathrm{p}<0.0000001$ and $\mathrm{p}=0.011$, respectively). These results show that PIK3R1 underexpression predominantly occurred in tumors with poorer prognostic markers (Additional file 5: Table S5). The combination of these two molecular markers (PIK3CA mutations and PIK3R1 underexpression) can be considered to provide more accurate prediction of patient survival than when they are considered separately. Combined analysis of PIK3CA mutations and PIK3R1 expression status defined four separate prognostic groups with significantly different survivals. Comparison of all four survival curves showed statistical differences with $\mathrm{p}=0.00046$ (log-rank test for 4-level factor, Figure 2). The least favorable survival was observed in the subgroup characterized by PIK3CA wild-type and PIK3R1 underexpression and the most favorable survival was observed in the subgroup characterized by $P I K 3 C A$ mutation without PIK3R1 underexpression.

Multivariate analysis using a Cox proportional hazards model (Table 5) assessed the predictive value for MFS of the parameters found to be significant on univariate analysis (i.e., Scarff-Bloom-Richardson histological grade, lymph node status, macroscopic tumor size, and ER $\alpha$, PR, and ERBB2 status, as well as PIK3CA mutation and PIK3R1 expression status). This analysis confirmed a trend towards an independent prognostic significance of PIK3CA mutations only in ERBB2+ tumors $(\mathrm{p}=0.051)$.
Furthermore, the prognostic significance of PIK3R1 underexpression persisted in the overall series $(\mathrm{p}=0.0013)$ and in breast cancer subgroups characterized by ER $\alpha+$ $(\mathrm{p}=0.0076), \mathrm{PR}+(\mathrm{p}=0.043)$, ERBB2+ $(\mathrm{p}=0.018)$ and also ERBB2- $(\mathrm{p}=0.024)$.

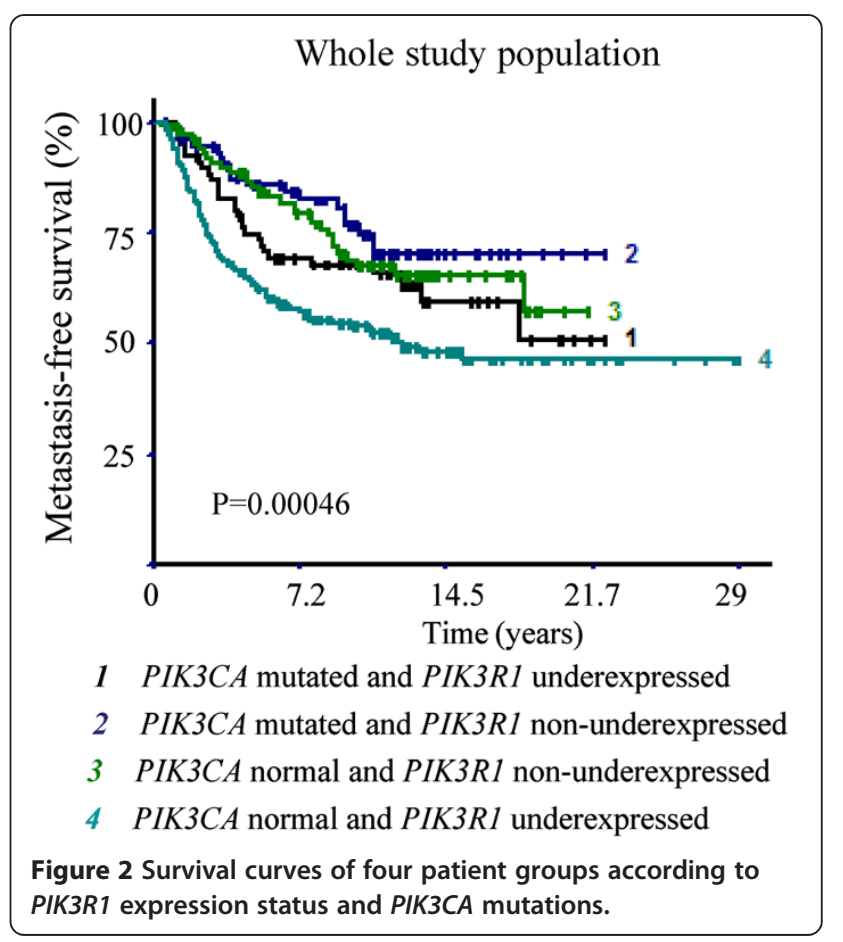


Table 5 Results of Cox multivariate analysis

\begin{tabular}{|c|c|c|c|c|c|c|c|c|c|c|c|c|c|c|}
\hline \multirow[t]{2}{*}{ Variables } & \multicolumn{2}{|c|}{ Total population } & \multirow{2}{*}{$\begin{array}{c}\text { ER-positive } \\
\mathrm{HR} \\
(95 \% \mathrm{Cl})^{\mathrm{a}}\end{array}$} & \multirow{2}{*}{$\frac{\text { patients }}{P \text {-value }}$} & \multirow{2}{*}{$\begin{array}{c}\text { ER-negative } \\
\mathrm{HR} \\
(95 \% \mathrm{Cl})^{\mathrm{a}}\end{array}$} & \multirow{2}{*}{$\frac{\text { patients }}{P \text {-value }}$} & \multirow{2}{*}{$\begin{array}{c}\text { PR-positive } \\
\mathrm{HR} \\
(95 \% \mathrm{Cl})^{\mathrm{a}}\end{array}$} & \multirow{2}{*}{$\frac{\text { patients }}{\text { P-value }^{\mathrm{b}}}$} & \multicolumn{2}{|c|}{ PR-negative patients } & \multicolumn{2}{|c|}{ ERBB2-positive patients } & \multicolumn{2}{|c|}{$\begin{array}{l}\text { ERBB2-negative } \\
\text { patients }\end{array}$} \\
\hline & $\begin{array}{c}\text { HR } \\
(95 \% \mathrm{Cl})^{\mathrm{a}}\end{array}$ & $P$-value ${ }^{b}$ & & & & & & & $\mathrm{HR}(95 \% \mathrm{Cl})^{\mathrm{a}}$ & $P$-value ${ }^{b}$ & $\mathrm{HR}(95 \% \mathrm{Cl})^{\mathrm{a}}$ & $P$-value ${ }^{b}$ & $\mathrm{HR}(95 \% \mathrm{CI})^{\mathrm{a}}$ & $P$-value ${ }^{\mathrm{b}}$ \\
\hline \multicolumn{15}{|l|}{ SBR } \\
\hline । & 1 & & 1 & & & & 1 & & & & & & 1 & \\
\hline$\|$ & $\begin{array}{c}1.27 \\
(1.01-1.61)\end{array}$ & 0.041 & $\begin{array}{c}1.42 \\
(1.06-1.90)\end{array}$ & 0.018 & & NS & $\begin{array}{c}1.87 \\
(1.30-2.68)\end{array}$ & 0.00068 & & NS & & NS & $1.49(1.14-1.95)$ & 0.0034 \\
\hline III & $\begin{array}{c}1.62 \\
(1.02-2.59)\end{array}$ & & $\begin{array}{c}2.02 \\
(1.13-3.61)\end{array}$ & & & & $\begin{array}{c}3.49 \\
(1.70-7.17)\end{array}$ & & & & & & $2.23(1.31-3.82)$ & \\
\hline \multicolumn{15}{|l|}{$p N$} \\
\hline 0 & 1 & & 1 & & 1 & & 1 & & 1 & & 1 & & & \\
\hline $1-3$ & $\begin{array}{c}1.54 \\
(1.22-1.93)\end{array}$ & 0.00021 & $\begin{array}{c}1.53 \\
(1.16-2.01)\end{array}$ & 0.0024 & $\begin{array}{c}1.61 \\
(1.08-2.40)\end{array}$ & 0.02 & $\begin{array}{c}1.57 \\
(1.12-2.22)\end{array}$ & 0.0097 & $1.53(1.13-2.07)$ & 0.0055 & $2.91(1.82-4.64)$ & 0.0000076 & & NS \\
\hline$>3$ & $\begin{array}{c}2.36 \\
(1.50-3.72)\end{array}$ & & $\begin{array}{c}2.34 \\
(1.35-4.04)\end{array}$ & & $\begin{array}{c}2.58 \\
(1.16-5.74)\end{array}$ & & $\begin{array}{c}2.47 \\
(1.24-4.91)\end{array}$ & & $2.34(1.28-4.28)$ & & $8.47(3.32-21.57)$ & & & \\
\hline \multicolumn{15}{|l|}{ pT } \\
\hline$\leq 25 \mathrm{~mm}$ & 1 & & 1 & & & & 1 & & & & & & 1 & \\
\hline$>25 \mathrm{~mm}$ & $\begin{array}{c}1.62 \\
(1.17-2.24)\end{array}$ & 0.004 & $\begin{array}{c}2.16 \\
(1.45-3.20)\end{array}$ & 0.00014 & & NS & $\begin{array}{c}2.22 \\
(1.38-3.55)\end{array}$ & 0.00096 & & NS & & NS & $1.97(1.36-2.86)$ & 0.00034 \\
\hline \multicolumn{15}{|l|}{$E R$} \\
\hline $\begin{array}{l}\text { Negative } \\
\text { Positive }\end{array}$ & & NS & & - & & - & & NS & & NS & & NS & & NS \\
\hline \multicolumn{15}{|l|}{$P R$} \\
\hline $\begin{array}{l}\text { Negative } \\
\text { Positive }\end{array}$ & & NS & & NS & & NS & & - & & - & & NS & & NS \\
\hline \multicolumn{15}{|l|}{ ERBB2 } \\
\hline $\begin{array}{l}\text { Negative } \\
\text { Positive }\end{array}$ & & NS & & NS & & NS & & NS & & NS & & - & & - \\
\hline PIK3R1 & & & & & & & & & & & & & & \\
\hline Underexpression & 1 & & 1 & & & & 1 & & & & 1 & & 1 & \\
\hline Normal & $\begin{array}{c}0.59 \\
(0.43-0.81)\end{array}$ & 0.0013 & $\begin{array}{c}0.62 \\
(0.44-0.88)\end{array}$ & 0.0076 & & NS & $\begin{array}{c}0.65 \\
(0.43-0.99)\end{array}$ & 0.043 & & NS & $0.40(0.19-0.85)$ & 0.018 & $0.66(0.46-0.95)$ & 0.024 \\
\hline
\end{tabular}


Table 5 Results of Cox multivariate analysis (Continued)

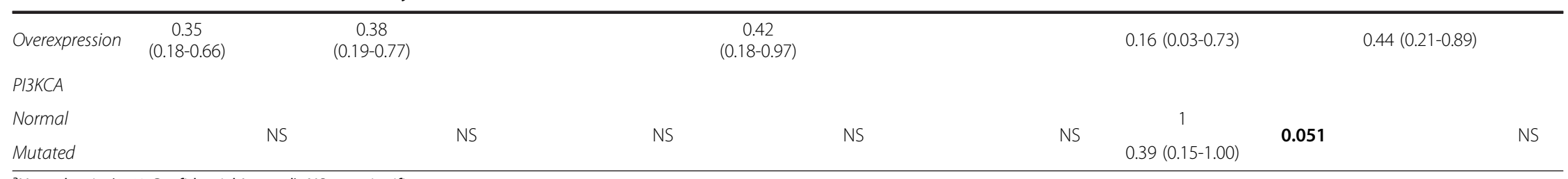

Hazard ratio (95\% Confidential Interval). NS: not significant.

${ }^{b}$ Multivariate Cox analysis. NS: not significant.

The bold numbers stress important finding or overall characterisation of a group or p-value. 


\section{Discussion}

This study extends the previously obtained data concerning the positive prognostic role of exon 9 and 20 PIK3CA mutations in breast cancer [12]. This study focused on PI3K signaling pathway, particularly the two subunits of PI3K encoded by PIK3CA and PIK3R1 genes. In addition to our previous study, PIK3CA mutations were also assessed in exons 1 and 2 that have been recently shown to be frequently mutated in endometrial cancer [15]. PIK3CA mutations were detected in 33.0\% of cases (exons 1, 2, 9, 20) and PIK3R1 mutations were detected in $2.2 \%$ of cases (exons 11, 12, 13, 15). The low frequency of about 3\% PIK3R1 mutations is in agreement with published studies $[17,28]$. AKT1 mutations (exon 4) were also assessed and detected in $3.3 \%$ of tumors. This finding is also in agreement with previous studies describing a moderate frequency of AKT1 mutations in breast cancer and their association with positive hormone receptor status [6]. PIK3CA, PIK3R1 and $A K T 1$ mutations were mutually exclusive and were observed in a total of 175 breast cancer tumors. Interestingly, PIK3R1 underexpression was observed in $61.8 \%$ of breast cancer tumors. PIK3CA mutations were associated with better MFS and PIK3R1 underexpression was associated with poorer MFS ( $\mathrm{p}=0.014$ and $\mathrm{p}=0.00028$, respectively). By combining PIK3CA mutation and PIK3R1 expression states, we identified four prognostic groups with significantly different MFS $(\mathrm{p}=0.00046)$. These new results suggest that PIK3CA mutations and PIK3R1 underexpression are associated with opposite prognostic impacts on breast cancer patient survival. Multivariate analysis showed that PIK3R1 expression status was an independent predictor of MFS in the total population $(\mathrm{p}=0.0013)$, whereas PIK3CA mutation status only showed a trend in the ERBB2+ population $(\mathrm{p}=$ $0.051)$.

The frequency and associations of genomic and protein expression alterations in the PI3K pathway differ in the various breast cancer subgroups. Additionally, some alterations may co-exist, while others are mutually exclusive. Mutually exclusive mutations have been previously reported for PIK3CA and AKT1 mutations [4]. We and other teams have found PIK3CA mutations in 10 to $40 \%$ of breast cancer cases and $A K T 1$ mutations in less than $10 \%$ of cases $[3-6,8,17]$. Our data are in agreement with the mutational frequencies described by other authors. Our findings also support the data recently published by Ellis et al., who described a low frequency of exon 1 and 2 mutations in breast cancer. They also observed missense mutations in these two exons occurring in cases bearing additional PIK3CA mutations, whereas one deletion in exon 1 was not accompanied by another PIK3CA mutation [29]. The most frequent mutations were E542K and E545K in exon 9 and H1047R in exon
20 in keeping with most other studies $[4,8,17,18]$. We also found that PIK3R1 mutations tended to mutual exclusivity with PIK3CA and AKT1 mutations. PTEN loss occurring in up to $30 \%$ of unselected breast tumor cohorts is also predominantly mutually exclusive with PIK3CA and AKT1 mutations $[4,18]$. PIK3R1 mutations as well as combined mutations of the three genes studied were also found to be mutually exclusive with PTEN underexpression $(\mathrm{p}=0.00016)$. As PIK3CA and AKT1 are oncogenes activated by mutations and as PIK3R 1 and PTEN are tumor suppressors mainly inactivated by underexpression, respectively, all these alterations result in PI3K pathway activation. The frequencies of PIK3CA, PIK3R1 and AKT1 alteration differ according to breast cancer subtypes. PIK3CA mutations have been previously described to occur most frequently in $\mathrm{HR}+$ breast tumors $[4,12]$. The highest mutational frequency for all of the genes assessed in this study (PIK3CA and/or PIK3R1 and/or AKT1) was observed in HR+/ERBB2- tumors $(133 / 289 ; 46.0 \%)$, while mutations were observed in up to $28 \%$ of cases in other breast cancer subtypes. In terms of expression, PIK3R1 was underexpressed in about $90 \%$ of HR- tumors, but only in about $55 \%$ of HR + breast cancers. Similarly, PTEN underexpression was observed in $40 \%$ of triple-negative tumors versus $13 \%$ in other breast cancer subtypes, suggesting different mechanisms underlining PI3K pathway deregulation in specific breast tumor subtypes.

The protein $\mathrm{p} 85 \alpha$ encoded by the PIK3R1 gene has been described to play an important role in PI3K pathway signaling by stabilizing the other PI3K subunit p110 $\alpha$ - encoded by PIK3CA gene $[7,16,30]$. Loss of the p85 $\alpha$ tumor suppressor effect leads to downstream PI3K pathway activation. The impact of PIK3R1 deregulation on pathway signaling could be caused by the impaired ability of interaction of the two subunits and loss of the inhibitory effect of $\mathrm{p} 85 \alpha$ on $\mathrm{p} 110 \alpha$ and PI3K activity $[7,28]$. PIK3R1 has been reported to play a tumor suppressor role in hepatocellular cancer and this tumor suppressor effect is lost in the case of gene underexpression $[11,16]$. Mostly point mutations and deletions have been reported for PIK3R1, but much less frequently in breast cancer ( $<5 \%$ of cases) than in other cancer types, such as endometrial cancer (about $20 \%$ of cases) [15,28]. PIK3R1 mutations were observed in $2.2 \%$ of cases in the present study. PIK3R1 mutations and p85 loss have also been associated with PI3K pathway activation and increased oncogenic potential. However, the fact that PIK3R1 mutations are rare in breast cancer indicates that PIK3R1 mRNA/p85 $\alpha$ expression loss is the main deregulation occurring in breast tumors, particularly in HR- breast tumors. Another player affecting the PI3K pathway activation is PTEN, a tumor suppressor phosphatase which negatively regulates the PI3K pathway. Loss of PTEN 
expression is frequently observed in various cancer types and in up to $30 \%$ of breast cancers, leading to PI3K pathway activation [4]. Interestingly, p85 has also been suggested to have a positive regulatory effect on PTEN function via stabilization of this protein $[15,16]$. PTEN underexpression was found in $17 \%$ cases in our series (39\% in triple-negative tumors) and was associated with PIK3CA wild-type status and PIK3R1 underexpression, in line with previous findings.

There is growing evidence in the literature concerning the favorable outcome of PIK3CA-mutated breast cancer, as supported by the results of this study [9-12]. These mutations are known to play an activating role in cell lines and animal models [13,14]. Several hypotheses are currently proposed to explain the favorable prognostic impact of PIK3CA mutations: 1, PIK3CA mutations, when they are the only hit to the PI3K signaling pathway, have a limited oncogenic potential; 2, PIK3CA mutations result in oncogene-induced senescence; $3, P I K 3 C A$ mutation-bearing cells are more sensitive to chemotherapy and/or other treatment modalities; 4, PIK3CA mutationinduced signaling triggers a negative feedback loop inhibiting lower levels of the pathway $[8,31]$. PIK3CA mutations might affect the PI3K/AKT pathway in different ways in patient tumors and cell lines. The difference between PIK3CA mutation-related activation of the pathway in cell lines or animal models and patient outcome could be related to the treatment received by patients, as suggested above. In contrast with the PIK3CA mutationassociated survival advantage in anti-ERBB2 untreated patients, PIK3CA mutations appear to predict resistance to treatment including ERBB2 inhibitors such as trastuzumab $[32,33]$.

The present study demonstrates that PIK3R1 underexpression is associated with decreased patient survival. Immunohistochemical analysis showed that PIK3R1 transcripts are translated into p85 protein in epithelial tumor cells (Figure 1). A strong correlation was also demonstrated between PIK3R1 mRNA underexpression and decreased p85 protein levels. Immunohistochemistry could be the method of choice to routinely determine p85 expression status. PIK3R1 underexpressing tumors were also prone to accumulate other changes of the PI3K/AKT pathway, i.e. PDK1 overexpression and EGFR, AKT3, PTEN and WEE1 underexpressions. PIK3R1 underexpression is therefore associated with additional pathway deregulation and possibly also with increased signaling activation. In a murine model with liver-specific PIK3R1 loss, this condition led to development of aggressive hepatocellular cancer [16]. Loss of PIK3R1 mRNA expression in cell lines was associated with a more migratory and more invasive phenotype of MCF7-14 cells compared to the parental MCF-7 cell line [34]. Lu et al. described a gene expression signature including
PIK3R1 distinguishing between low- and high-risk stage I lung cancer. The authors found low PIK3R1 expression in high-risk compared to low-risk lung cancers [35]. Studies concerning glioblastomas have also suggested that these tumors might be negatively influenced by PIK3R1 expression at the level of cell lines and in terms of patient survival [36,37]. The recently observed role of PIK3R1 expression deregulation in breast cancer survival needs to be further assessed, preferably in a prospective clinical study.

Our results suggest that PIK3R1 could potentially become a clinically useful independent prognostic marker in breast cancer. PIK3R1 underexpression (as well PIK3CA mutation) might also predict a favorable response to treatment with PI3K inhibitors or inhibitors of lower levels of the signaling pathway, such as mTOR inhibitors $[14,28,38,39]$. Finally, PIK3R1 underexpression (and PIK3CA mutation) could be explored as predictors of resistance to treatment with ERBB2 inhibitors such as trastuzumab [12].

\section{Conclusions}

PIK3CA and PIK3R1 are genes encoding two subunits of the PI3K enzyme, $\mathrm{p} 110 \alpha$ and $\mathrm{p} 85 \alpha$, respectively. The present study showed that alterations in these two genes have a complementary impact on breast cancer patient survival. There is growing evidence supporting PIK3CA mutations as good prognostic markers in breast cancer, but the negative impact of PIK3R1 underexpression on patient survival has been less extensively studied. These two potential tumor markers warrant further assessment, preferably in prospective clinical studies.

\section{Additional files}

Additional file 1: Table S1. Characteristics of the 458 primary breast tumors.

Additional file 2: Table S2. Oligonucleotide primer sequences for RT-PCR analysis.

Additional file 3: Table S3. List of PIK3R1 mutations found in the present study.

Additional file 4: Table S4. Relationship between gene status and MFS

Additional file 5: Table S5. Characteristics of the 458 primary breast tumors correlated with PIK3R1 expression status.

\section{Abbreviations}

PIK3CA: Phosphatidylinositol 3-kinase, catalytic, alpha polypeptide gene; PIK3R1: Phosphatidylinositol 3-kinase, regulatory subunit 1 (alpha); PI3K: Phosphatidylinositol 3-kinase; RFS: Relapse-free survival; ERa: Estrogen receptor alpha; PR: Progesterone receptor; HR: Hormone receptors; RT-PCR: Reverse transcriptase-polymerase chain reaction.

\section{Competing interests}

The authors declare that they have no competing interests. 


\section{Author's contributions}

IB conceived and designed the study, supervised the study and participated on data analysis and interpretation. SV, AS, DM and MT participated on data acquisition. MC participated on data analysis and interpretation and on writing and revising the manuscript. DM, CC, ER and FS participated on analysis and interpretation of data. RL participated on data analysis and interpretation and on writing and revising the manuscript. All authors read and approved the final maunscript.

\section{Acknowledgements}

This work was supported by the Conseil régional d'lle-de-France, the Cancéropôle lle-de-France and the Comité départemental des Hauts-deSeine de la Ligue Nationale Contre le Cancer. The work was partly supported by IGA UP LF_2013_015 grant. We thank Jana Vrbkova and Sandra Donevska for statistical analysis and helpful discussion.

\section{Author details}

'Oncogenetic Laboratory, Institut Curie, Hospital René Huguenin, Saint-Cloud, France. ${ }^{2}$ Department of Oncology, Faculty of Medicine and Dentistry, Palacky University and University Hospital Olomouc, Olomouc, Czech Republic.

${ }^{3}$ Laboratory of Experimental Medicine, Institute of Molecular and Translational Medicine, Faculty of Medicine and Dentistry, Palacky University and University Hospital Olomouc, Olomouc, Czech Republic. ${ }^{4}$ Department of Pathology, Institut Curie, Hospital René Huguenin, Saint-Cloud, France. ${ }^{5}$ UMR745 INSERM, Université Paris Descartes, Sorbonne Paris Cité, Faculté des Sciences Pharmaceutiques et Biologiques, Paris, France. ' ${ }^{6}$ Laboratoire d’Oncogénétique, 35 rue Dailly, Institut Curie - Hôpital René Huguenin, St-Cloud F-92210, France.

Received: 11 June 2013 Accepted: 28 October 2013

Published: 14 November 2013

\section{References}

1. Katayama K, Fujita N, Tsuruo T: Akt/protein kinase B-dependent phosphorylation and inactivation of WEE1Hu promote cell cycle progression at G2/M transition. Mol Cell Biol 2005, 25:5725-5737.

2. Scott KL, Kabbarah O, Liang MC, Ivanova E, Anagnostou V, Wu J, Dhakal S, Wu M, Chen S, Feinberg T, Huang J, Saci A, Widlund HR, Fisher DE, Xiao Y, Rimm DL, Protopopov A, Wong KK, Chin L: GOLPH3 modulates mTOR signalling and rapamycin sensitivity in cancer. Nature 2009, 459:1085-1090

3. Baselga J: Targeting the phosphoinositide-3 (PI3) kinase pathway in breast cancer. Oncologist 2011, 16(Suppl 1):12-19.

4. Stemke-Hale K, Gonzalez-Angulo AM, Lluch A, Neve RM, Kuo WL, Davies M, Carey M, Hu Z, Guan Y, Sahin A, Symmans WF, Pusztai L, Nolden LK, Horlings $H$, Berns K, Hung MC, van de Vijver MJ, Valero V, Gray JW, Bernards R, Mills GB, Hennessy BT: An integrative genomic and proteomic analysis of PIK3CA, PTEN, and AKT mutations in breast cancer. Cancer Res 2008 , 68:6084-6091.

5. Dunlap J, Le C, Shukla A, Patterson J, Presnell A, Heinrich MC, Corless CL, Troxell ML: Phosphatidylinositol-3-kinase and AKT1 mutations occur early in breast carcinoma. Breast Cancer Res Treat 2010, 120:409-418.

6. Castaneda CA, Cortes-Funes H, Gomez HL, Ciruelos EM: The phosphatidyl inositol 3-kinase/AKT signaling pathway in breast cancer. Cancer Metastasis Rev 2010, 29:751-759.

7. Shekar SC, Wu H, Fu Z, Yip SC, Nagajyothi Cahill SM, Girvin ME, Backer JM: Mechanism of constitutive phosphoinositide 3-kinase activation by oncogenic mutants of the p85 regulatory subunit. J Biol Chem 2005, 280:27850-27855

8. Barbareschi M, Buttitta F, Felicioni L, Cotrupi S, Barassi F, Del Grammastro M, Ferro A, Dalla Palma P, Galligioni E, Marchetti A: Different prognostic roles of mutations in the helical and kinase domains of the PIK3CA gene in breast carcinomas. Clin Cancer Res 2007, 13:6064-6069.

9. Maruyama N, Miyoshi Y, Taguchi T, Tamaki Y, Monden M, Noguchi S Clinicopathologic analysis of breast cancers with PIK3CA mutations in Japanese women. Clin Cancer Res 2007, 13:408-414.

10. Pérez-Tenorio G, Alkhori L, Olsson B, Waltersson MA, Nordenskiöld B, Rutqvist LE, Skoog L, Stål O: PIK3CA mutations and PTEN loss correlate with similar prognostic factors and are not mutually exclusive in breast cancer. Clin Cancer Res 2007, 13:3577-3584.

11. Kalinsky K, Jacks LM, Heguy A, Patil S, Drobnjak M, Bhanot UK, Hedvat CV, Traina TA, Solit D, Gerald W, Moynahan ME: PIK3CA mutation associates with improved outcome in breast cancer. Clin Cancer Res 2009 15:5049-5059.

12. Cizkova M, Susini A, Vacher S, Cizeron-Clairac G, Andrieu C, Driouch K, Fourme $E$, Lidereau $R$, Bièche I: PIK3CA mutation impact on survival in breast cancer patients and in ERa, PR and ERBB2-based subgroups. Breast Cancer Res 2012, 14:R28.

13. Zhao JJ, Liu Z, Wang L, Shin E, Loda MF, Roberts TM: The oncogenic properties of mutant p110alpha and p110beta phosphatidylinositol 3-kinases in human mammary epithelial cells. Proc Natl Acad Sci U S A 2005, 102:18443-18448.

14. Bader AG, Kang S, Vogt PK: Cancer-specific mutations in PIK3CA are oncogenic in vivo. Proc Natl Acad Sci U S A 2006, 103:1475-1479.

15. Cheung LW, Hennessy BT, Li J, Yu S, Myers AP, Djordjevic B, Lu Y, StemkeHale K, Dyer MD, Zhang F, Ju Z, Cantley LC, Scherer SE, Liang H, Lu KH, Broaddus RR, Mills G: High frequency of PIK3R1 and PIK3R2 mutations in endometrial cancer elucidates a novel mechanism for regulation of PTEN protein stability. Cancer Discov 2011, 1:170-185.

16. Taniguchi CM, Winnay J, Kondo T, Bronson RT, Guimaraes AR, Alemán JO, Luo J, Stephanopoulos G, Weissleder R, Cantley LC, Kahn CR: The phosphoinositide 3-kinase regulatory subunit p85alpha can exert tumor suppressor properties through negative regulation of growth factor signaling. Cancer Res 2010, 70:5305-5315.

17. Network CGA: Comprehensive molecular portraits of human breast tumours. Nature 2012, 49:61-70.

18. Saal LH, Holm K, Maurer M, Memeo L, Su T, Wang X, Yu JS, Malmström PO, Mansukhani M, Enoksson J, Hibshoosh H, Borg A, Parsons R: PIK3CA mutations correlate with hormone receptors, node metastasis, and ERBB2, and are mutually exclusive with PTEN loss in human breast carcinoma. Cancer Res 2005, 65:2554-2559.

19. Li SY, Rong M, Grieu F, lacopetta B: PIK3CA mutations in breast cancer are associated with poor outcome. Breast Cancer Res Treat 2006, 96:91-95.

20. Bièche I, Onody P, Laurendeau I, Olivi M, Vidaud D, Lidereau R, Vidaud M: Real-time reverse transcription-PCR assay for future management of ERBB2-based clinical applications. Clin Chem 1999, 45:1148-1156.

21. Bièche I, Parfait B, Laurendeau I, Girault I, Vidaud M, Lidereau: Quantification of estrogen receptor alpha and beta expression in sporadic breast cancer. Oncogene 2001, 20:8109-8115.

22. Onody P, Bertrand F, Muzeau F, Bièche I, Lidereau R: Fluorescence in situ hybridization and immunohistochemical assays for HER-2/neu status determination: application to node-negative breast cancer. Arch Pathol Lab Med 2001, 125:746-750.

23. Bossard C, Bieche I, Le Doussal V, Lidereau R, Sabourin JC: Real-time RT-PCR: a complementary method to detect HER-2 status in breast carcinoma. Anticancer Res 2005, 25:4679-4683.

24. Kaplan EL, Meier P: Nonparametric estimation from incomplete observations. J Am Stat Assoc 1958, 53:457-481.

25. Peto R, Pike MC, Armitage P: Design and analysis of randomized clinical trials requiring prolonged observation of each patient: II: analysis and examples. Br J Cancer 1977, 35:1-39.

26. Cox DR: Regression models and life-tables. J R Stat Soc Series B Stat Methodol 1972, 34:187-220.

27. Meseure D, Vacher S, Drak Alsibai K, Trassard M, Susini A, Le Ray C, Lerebours F, Le Scodan R, Spyratos F, Marc Guinebretiere J, Lidereau R, Bieche I: Profiling of EGFR mRNA and protein expression in 471 breast cancers compared with 10 normal tissues: a candidate biomarker to predict EGFR inhibitor effectiveness. Int J Cancer 2012, 131:1009-1010.

28. Jaiswal BS, Janakiraman V, Kljavin NM, Chaudhuri S, Stern HM, Wang W, Kan Z, Dbouk HA, Peters BA, Waring P, Dela Vega T, Kenski DM, Bowman KK, Lorenzo M, Li H, Wu J, Modrusan Z, Stinson J, Eby M, Yue P, Kaminker JS, de Sauvage FJ, Backer JM, Seshagiri S: Somatic mutations in p85alpha promote tumorigenesis through class IA PI3K activation. Cancer Cell 2009, $16: 463-474$

29. Ellis MJ, Ding L, Shen D, Luo J, Suman VJ, Wallis JW, Van Tine BA, Hoog J, Goiffon RJ, Goldstein TC, Ng S, Lin L, Crowder R, Snider J, Ballman K, Weber J, Chen K, Koboldt DC, Kandoth C, Schierding WS, McMichael JF, Miller CA, Lu C, Harris CC, McLellan MD, Wendl MC, DeSchryver K, Allred DC, Esserman L, Unzeitig G, Margenthaler J, Babiera GV, Marcom PK, Guenther JM, Leitch M, Hunt K, Olson J, Tao Y, Maher CA, Fulton LL, Fulton RS, Harrison M, Oberkfell B, Du F, Demeter R, Vickery TL, Elhammali A, Piwnica-Worms H, McDonald S, Watson M, Dooling DJ, Ota D, Chang LW, Bose R, Ley TJ, Piwnica-Worms D, Stuart JM, Wilson RK, Mardis ER: Whole-genome analysis 
informs breast cancer response to aromatase inhibition. Nature 2012, 486:353-360.

30. Yu J, Zhang Y, Mcllroy J, Rordorf-Nikolic T, Orr GA, Backer JM: Regulation of the p85/p110 phosphatidylinositol 3'-kinase: stabilization and inhibition of the p110alpha catalytic subunit by the p85 regulatory subunit. Mol Cell Biol 1998, 18:1379-1387.

31. Di Cosimo S, Baselga J: Phosphoinositide 3-kinase mutations in breast cancer: a "good" activating mutation? Clin Cancer Res 2009, 15:5017-5019.

32. Dave B, Migliaccio I, Gutierrez MC, Wu MF, Chamness GC, Wong H, Narasanna A, Chakrabarty A, Hilsenbeck SG, Huang J, Rimawi M, Schiff R, Arteaga C, Osborne CK, Chang JC: Loss of phosphatase and tensin homolog or phosphoinositol-3 kinase activation and response to trastuzumab or lapatinib in human epidermal growth factor receptor 2-overexpressing locally advanced breast cancers. J Clin Oncol 2011, 29:166-173.

33. Jensen JD, Knoop A, Laenkholm AV, Grauslund M, Jensen MB, Santoni-Rugiu E, Andersson M, Ewertz M: PIK3CA mutations, PTEN, and pHER2 expression and impact on outcome in HER2-positive early-stage breast cancer patients treated with adjuvant chemotherapy and trastuzumab. Ann Oncol 2012, 23:2034-2042

34. Uchino M, Kojima H, Wada K, Imada M, Onoda F, Satofuka H, Utsugi T, Murakami Y: Nuclear beta-catenin and CD44 upregulation characterize invasive cell populations in non-aggressive MCF-7 breast cancer cells. BMC Cancer 2010, 10:414

35. Lu Y, Lemon W, Liu PY, Yi Y, Morrison C, Yang P, Sun Z, Szoke J, Gerald WL, Watson M, Govindan R, You M: A gene expression signature predicts survival of patients with stage I non-small cell lung cancer. PLoS Med 2006, 3:e467.

36. Serão NV, Delfino KR, Southey BR, Beever JE, Rodriguez-Zas SL: Cell cycle and aging, morphogenesis, and response to stimuli genes are individualized biomarkers of glioblastoma progression and survival. BMC Med Genomics 2011, 4:49.

37. Weber GL, Parat MO, Binder ZA, Gallia GL, Riggins GJ: Abrogation of PIK3CA or PIK3R1 reduces proliferation, migration, and invasion in glioblastoma multiforme cells. Oncotarget 2011, 2:833-849.

38. Tanaka H, Yoshida M, Tanimura H, Fujii T, Sakata K, Tachibana Y, Ohwada J, Ebiike H, Kuramoto S, Morita K, Yoshimura Y, Yamazaki T, Ishii N, Kondoh O, Aoki Y: The selective class I PI3K inhibitor CH5132799 targets human cancers harboring oncogenic PIK3CA mutations. Clin Cancer Res 2011, 17:3272-3281

39. Kataoka Y, Mukohara T, Shimada H, Saijo N, Hirai M, Minami H: Association between gain-of-function mutations in PIK3CA and resistance to HER2-targeted agents in HER2-amplified breast cancer cell lines. Ann Oncol 2010, 21:255-262.

doi:10.1186/1471-2407-13-545

Cite this article as: Cizkova et al:: PIK3R1 underexpression is an independent prognostic marker in breast cancer. BMC Cancer 2013 13:545.

\section{Submit your next manuscript to BioMed Central and take full advantage of:}

- Convenient online submission

- Thorough peer review

- No space constraints or color figure charges

- Immediate publication on acceptance

- Inclusion in PubMed, CAS, Scopus and Google Scholar

- Research which is freely available for redistribution 